from eighteen inches on the longer axis to the size of a bean, and from a spherical to an ellipsoidal figure.

We have not far to seek for their origin, as a visit to the lower edge of the peat frayed into a sort of subtidal cliff or series of cliffs by the encroachments of the sea shows a deposit of similar clay boulders at its base. In the neighbourhood of the trench the River Alt meandering over the shore has made great inroads on the PostGlacial deposits, which compose the substratum, forming a subtidal river cliff of blue clay on its western margin. Lumps of this clay undermined by the currents, fall, break up into pieces, and get rolled into boulders by the action of the tide. The trench has formed a sort of trap for catching and retaining them. The clayboulders are in contact, and become in the trench compacted together into one solid mass, so that if it were converted into rock its structure would show in some cases distinet argillaceous boulders in a sandy argillaceous matrix, and in others an imperceptible shading of the boulder nucleus into the matrix.

Simply describing the foregoing facts for the information of those interested, I leave geologists to apply the explanation to some of the conglomerates.

T. Mellard Reade.

\title{
SIR RICHARD GRIFFITH AND THE OLD RED SANDSTONE.
}

SIR,-The last big talk I had with the late Sir Richard Griffith was immediately before the British Association Meeting in Belfast, and it was on my work in West Galway and Mayo. Previous to it I had left my maps and sections with him to examine after explaining them. During this conversation we discussed the age of the Louisburgh Toormakeady and Croogh Moyle beds which had been examined and proved to be of Silurian age, and Griffith pointed out that the Curlew Mountain rocks and those near Firodes he always believed to be of the same age and to be about equivalent to the Dingle beds, " but I never," said he, "had time to examine them carefully, and I left them in the Old Red Sandstone because they were very like the conglomerates of the Comeraghs Galters and Knockmealdown Hills." He also pointed out that there was a decided unconformability in the rocks said to belong to the "Old Red Sandstone formation" in Ireland; while the newer rocks so called seemed to be on different geological horizons. He concluded by saying, "My work must remain as it is, but the working out of the question has still to be done," or words to that effect. Since then I have been carefully examining into the question, starting on what was suggested to me by Griffith, and the results of my labours will be found in my recently published Manual of Irish Geology. This is sufficient to say at the present, as I hope to enter fully into the history of the subject in a paper to be read before the Royal Geological Society of Ireland.

G. Henry Kinahan.

Ovoca, Ireland, 5th November, 1878. 